\title{
OUTBREAK OF LYMPHOGRANULOMA VENEREUM AMONG MEN WHO HAVE SEX WITH MEN IN BARCELONA $2007 / 08$ - AN OPPORTUNITY TO DEBATE SEXUAL HEALTH AT THE EUROGAMES 2008
}

\author{
M Vall Mayans (mvall.bcn.ics@gencat.cat) ${ }^{1}$, E Caballero ${ }^{2}$, P Garcia de Olalla 3 , P Armengol ${ }^{1}$, MG Codina ${ }^{2}$, MJ Barberà ${ }^{1}$, \\ B Sanz ${ }^{1}$, A Andreu$^{2}$, JA Caylà ${ }^{3}$ \\ 1. Sexually Transmitted Infections Unit, Primary Health Centre Drassanes, Catalan Health Institute, Barcelona, Catalonia, Spain \\ 2. Microbiology Service, University Hospital Vall d’Hebron, Catalan Health Institute, Barcelona, Catalonia, Spain \\ 3. Agència de Salut Pública (Public Health Agency, ASPB), Barcelona, Catalonia, Spain
}

Lymphogranuloma venereum (LGV) is a systemic sexually transmitted infection (STI) caused by Chlamydia trachomatis ( $\mathrm{L}$ serovars L1, L2 or L3). Since 2003, several outbreaks of rectal LGV affecting men who have sex with men (MSM) have occurred in western Europe [1].

The first case in Spain was confirmed in Barcelona in 2005 [2], but no further cases have been detected in this city since until September 2007. We briefly summarise the characteristics of the LGV cases diagnosed at the outpatient STI clinic in Barcelona between September 2007 and April 2008.

Rectal C. trachomatis was detected by means of nucleic acid amplification tests. Positive samples were then confirmed with a second real-time multiplex polymerase chain reaction that allows to distinguish serovars A-K from the L serovars [3].

The first case was diagnosed on 17 September 2007. Since then, there have been between two and three cases per month, with the exception of eight cases in April 2008. As of 30 April 2008, the total number of confirmed cases was 21 .

All cases were MSM and all except two were coinfected with human immunodeficiency virus (HIV). All patients were white, 11 cases originated from Spain, five came from other Europen Union countries and the remaining five from Latin America. They presented with an anorectal syndrome with proctitis, the symptoms persisting for a duration ranging between 3 and 60 days. Most of the cases had attended at least one known venue in Barcelona where the customers engage in risky sexual behaviour with casual partners.

LGV being a notifiable disease in Barcelona since 2007, all cases were notified to the Public Health Agency of Barcelona [4] in order to initiate contact tracing and health promotion activities. The following control measures were implemented in response: hospitals, HIV and public health specialists were alerted; information was disseminated through MSM magazines; and outreach interventions were performed in bathhouses.

Barcelona is going to host the celebration of the EuroGames in July 2008, a sports competition that aims to bring together all those - gays, lesbians, transexuals, bisexuals, heterosexuals - who believe in diversity, openness and equality among people. The event, sponsored by non-governmental as well as governmental organisations, will include sport, culture, debates and fun [http:// www.panteresgrogues.cat/cms/]. 15,000 people are expected during the opening ceremony followed by a great parade. In our opinion, this would be a good opportunity to debate sexual health issues in light of the increasing rates of STI which disproportionately affect some groups of MSM in western Europe [5].

Increases in syphilis infections in high-income settings of several major cities have been well characterised over the last five to 10 years [6]. In Barcelona, the reemergence of this disease was detected in 2001. MSM diagnosed with syphilis in the outpatient STI clinic in Barcelona have an HIV coinfection rate of 36\% [7]. An increasing number of cases in 2006, with similar rates of HIV coinfection, suggests that ongoing transmission is taking place among MSM in this city. Without effective interventions, a worrying resurgence of STI among some groups of MSM can be anticipated [8]. Emerging STIs should make MSM, especially those living with HIV, aware of the importance of sexual health.

This outbreak of LGV in Barcelona, the first one in Spain, is similar to outbreaks in other major European cities. With cases probably linked, these outbreaks may result in the extension of STIs across Europe through core groups of MSM. Due to its serious consequences LGV already needs to be considered in the differential diagnosis of proctitis in Spain [9]. In light of the emergence of LGV in Europe, there is a role for public health agencies, MSM organisations and clinical services to limit the extent of STIs including HIV. The opportunity provided by the EuroGames 2008 in Barcelona to debate sexual health issues should certainly not to be missed.

\section{References}

1. Van de Laar MJ. The emergence of LGV in Western Europe: what do we know, what can we do?. Euro Surveill, 2006;11(9):pij=641. Available from: http:// www.eurosurveillance.org/ViewArticle.aspx?ArticleId=641

2. Vall Mayans M, Sanz Colomo B, Ossewaarde JM. First case of LGV confirmed in Barcelona. Euro Surveill. 2005;10(5):pii=2634. Available from: http://www. eurosurveillance.org/ViewArticle. aspx?ArticleId=2634 
3. Chen CY, Chi KH, Alexander S, Martin IM, Liu H, Ison CA, et al. The molecular diagnosis of lymphogranuloma venereum: evaluacion of a real-time multiplex polymerase chain reaction test using rectal and urethral specimens. Sex Transm Dis. 2007;34(7):451-5.

4. Generalitat de Catalunya. Departament de Salut. Manual de Notificació de les Malalties de Declaració Obligatòria per a l'any 2007. Direcció General de Salut Pública: Barcelona; December 2006. [In Catalan].

5. Fenton K. A multilevel approach to understanding the resurgence and evolution of infectious syphilis in Western Europe. Euro Surveill. 2004;9(12):pii=491. Available from: http://www.eurosurveillance.org/ ViewArticle.aspx?ArticleId $=491$

6. Fenton KA, Breban R, Vardavas R, Okano JT, Martin T, Aral S, et al. Infectious syphilis in high-income settings in the 21st century. Lancet Infect Dis. 2008;8(4):244-53.*

7. Vall-Mayans M, Casals M, Vives A, Loureiro E, Armengol P, Sanz B. Reemergence of infectious syphilis among homosexual men and HIV coinfection in Barcelona, 2002-2003. Med Clin (Barc). 2006;126(3):94-6. [In Spanish].

8. Vall-Mayans M, Vives A, Armengol $P$ et al. Ongoing transmission of syphilis in Barcelona after its reemergence amongst men who have sex with men in 2001. The 23rd IUSTI-Europe Conference on STI and HIV/AIDS. Cavtat/Dubrovnik, Croatia; October 11-14, 2007.

9. McMillan A, van Voorst Vader PC, de Vries HJ; International Union against Sexually Transmitted Infections/World Health Organization. The 2007 European Guideline (International Union against Sexually Transmitted Infections/ World Health Organization) on the management of proctitis, proctocolitis and enteritis caused by sexually transmissible pathogens. Int J STD AIDS. 2007;18(8):514-20.

This article was published on 19 June 2008.

Citation style for this article: Vall Mayans M, Caballero E, Garcia de Olalla P, Armengol P, Codina M, Barberà M, Sanz B, Andreu A, Caylà J. Outbreak of lymphogranuloma venereum among men who have sex with men in Barcelona 2007/08 - an opportunity to debate among men who have sex with men in Barcelona 2007/08 - an opportunity to debate sexual health at the EuroGames 2008. Euro Surveill. 2008;13(25):pii=18908. 